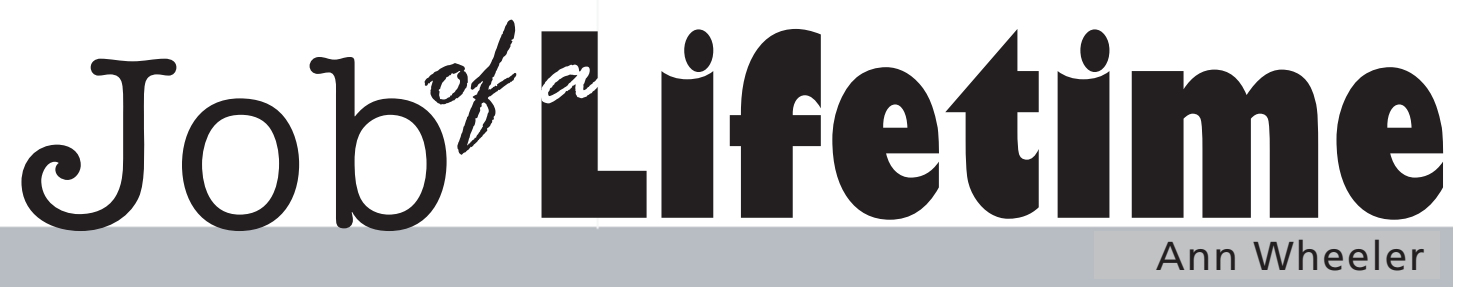

\title{
You can hear the smiles in Claudia Covert's voice
}

Although I'd never met Claudia Covert before, talking with her felt like chatting with an old friend. She has a gift for making people feel comfortable with her down-to-earth attitude, thoughtfulness, and easy laughter. She's the Readers' Services Librarian at the Rhode Island School of Design (RISD) in Providence, Rhode Island, where for the past two years, she's led the reference, instruction, and circulation staff at the library.

She's responsible for everything from day-to-day problem solving to big picture decisions, and is guiding the staff in exciting new directions. She gave me the scoop on what makes her job a job of a lifetime.

\section{It had to be art}

With an artistic mother, Covert has been surrounded by art since she was a little girl. "I can remember being in elementary school, when they were showing pictures of artists' work, and

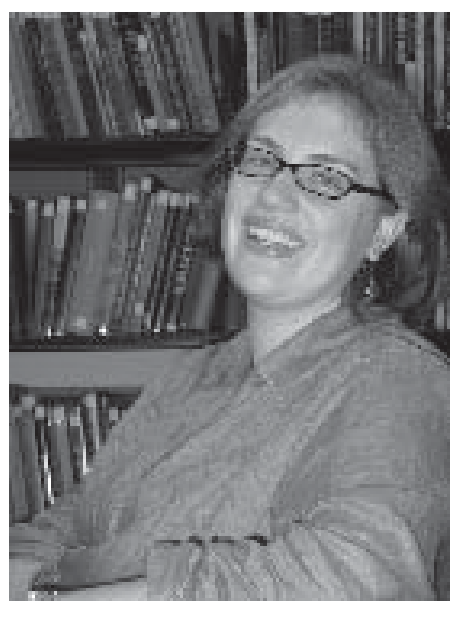

Claudia Covert
Covert brings a strong people-centered focus to her job. "My leading thing for the past two years has been better communication with the staff and the faculty," she said.

"I'm a people person, and I want people to feel empowered. I want to give them the tools to do that." This includes looking beyond the distinctions between professional and paraprofessional staff, all of whom she refers to as Readers' Services. "I keep stressing we're one department, and we're the public face of the library."

\section{Managing a move}

Covert's biggest project has been leading the Readers' Services staff through a library move to a space three times the size of the old library. "We were on top of each other in the old library," she said. "I was sharing the reference desk with Special Collections, and it was also a second circulation desk."

The move was a lot of work, I remember saying, 'Oh, that's Picasso's blue period." After earning her MLS, working in art libraries was a natural choice for Covert.

In addition to the books, periodicals, and database subscriptions found at most college libraries, RISD's collection includes 165,000 slides, which are "slowly but surely being digitized," and a picture collection, consisting of magazine clippings and images dating back to the late 19th century. "I love the ads from the '30s. If you need pictures of kitchen cabinets, there's a subject heading for that." but has been a rewarding experience. "You realize that space can cripple a library. Realizing, wow, I can actually do my job in a normal way, because I have a desk that's not the reference desk, where I can work and be undisturbed; that is really rewarding."

For any library staff, change can be stressful. "I think they were excited and nervous

Ann Wheeler is an adjunct faculty at Anne Arundel Community College. Have an idea for a job of a lifetime story? E-mail Ann at annkwheeler@yahoo.com . 
about the library move and what it meant." To support the staff, Covert began holding weekly meetings with a strict 30-minute time limit. "I wanted them to be useful. We met weekly for the six months prior to the library move and we're still meeting weekly."

A lot of good has come from these meetings. She learned, for example, that her staff was anxious about the new technology in the library. To address this, she ran a "technology walkthrough" in the library, where "everybody got to try every piece of equipment until they felt comfortable doing it." Even when nothing concrete comes from the meetings, her staff appreciate having them.

"Sometimes I feel like I've had three meetings and I've gotten nowhere on this topic. But then I go to the staff and they say, 'Well, we really appreciate it because

\section{Readers' services librarian}

What: Rhode Island School of Design

Where: Providence, Rhode Island

For more information, visit: www.risd.edu/risd_library.cfm at least we're talking. At least we're trying to streamline something."'

\section{Reaching out makes a difference}

Covert's gift for communication doesn't stop with staff. She's also reached out to the RISD faculty with exciting results. For example, she distributed a menu of library services available to the faculty. "They said, 'Wow, I didn't know you were that flexible, I didn't know I could team teach with you.' They just didn't know these options because they were never written down and offered to them before." Thanks to her outreach, she'll be team-teaching with faculty for the first time in the college's nature lab this fall. She's also hosting the library's first faculty brown bag lunch and dinner, which will focus on JSTOR and Project Muse.

Looking to the future, Covert says, "I think our two biggest challenges are going to be how our students change, and what technology gives us and how we adapt to that. I think communication and staff empowerment will help us address those challenges." Covert is always ready to learn from the students.
"I myself don't want to get to a point where I say, 'Oh, those kids, what are they doing?' I always want to be like, 'Okay, what are they doing?' and be excited about it! Are they using the tables in the open part of the library that are supposed to be quiet for group study and being really loud? Well, instead of going over and reprimanding them, let's find out how are they using the space, and what can we do to facilitate that. I mean, do we need to have loud hours at certain times?"

\section{It's all about the people}

It's no surprise that Covert's favorite thing about her job is the people she works with.

"I love when students come in and I help them with projects and they come back, and they say, 'Look what I did! This is how I finished my project with the information you gave me.' It's really exciting to see how, hopefully, I played a part." She's also played a big part in making the library a rewarding place to work.

"A staff member and I were having a conversation, and she said that Sunday nights used to be a really nervous evening for her because she knew she had work the next day. But now she enjoys coming to work. The communication, the ease of approach, that sort of thing has really helped her enjoy her job. That's what I enjoy too, that I've been able to do this for people, and people do this for me."

Covert encourages librarians to consider art librarianship. She loves working with visual communities, the meshing of images with text, and the interesting range of people she meets in art librarianship.

"ACRL has the art libraries section and there's the Art Library Society of North America. [There are] some great organizations out there. I would encourage anybody with an art interest to go this way." If you do, Covert is just the type of interesting, dynamic person you're sure to meet along the way. $z$ 